\title{
Tingkat Pengetahuan Dan Sikap Pedagang Makanan Jajanan Pasar Terhadap Penggunaan Pewarna Yang Dilarang Di Pasar-Pasar Kota Semarang
}

\author{
Knowledge Levels and Attitudes of Market Street Food Traders Against the Use of Dyes that Are Banned in \\ Semarang City Markets
}

Rila Dini Ayu Larasati ${ }^{1}$, Yuwono Setiadi $^{2}$,Dyah Nur Subandriani ${ }^{3}$,Arintina Rahayuni ${ }^{4}$,Ana Yuliah Rahmawati ${ }^{5}$

\section{ABSTRACT}

Background : The use of banned dyes In making foodin general to give a striking color to food so that it can attract consumers to buy, but the trader was not aware of the dangers of using banned dyes. This is because the level of knowledge and attitudes of food traders are less related to the use offood coloring agents.

Objective : Knowing the relationship between the level of knowledge and the attitude of market food vendors to the use of dyes that are prohibited in the Semarang city market.

Method : This research is a descriptive analytic study with cross sectional design. Sampling uses cluster techniques to 8 market samples. The collected data are knowledge and attitude data with questionnaire and interview measurement tools.Data on the use of dyesusing the phenylhydrazine method.

Results : Traders have knowledge in good categories (87,5\%)while traders have the same attitude comparison between those who support and not support (50\%)and the results of laboratory tests conducted by the university on August 17 showed negative results on the use of banned dyes but there were 2 markets using dyes that were not prohibited, namelyEritrosin.

Conclusion : All traders do not use dyes that are banned in cenil and putu mayang

Keywords : Knowledge, attitude, use of dyes are prohibited

\section{ABSTRAK}

Latar Belakang : Penggunaan zat pewarna yang dilarang pada pembuatan makanan jajanan pada umumnya untuk memberikan warna yang mencolok pada makanan sehingga dapat menarik konsumen untuk membeli, namun pada umumnya pedagang makanan jajanan tersebut tidak menyadari bahaya penggunaan zat pewarna yang dilarang. Hal ini karena tingkat pengetahuan dan sikap pedagang makanan jajanan yang kurang terkait penggunaan zat pewarna.

Tujuan : Mengetahui hubungan tingkat pengetahuan dan sikap pedagang makanan jajanan pasar terhadap penggunaan pewarna yang dilarang di pasar-pasar Kota Semarang.

Metode : Penelitian ini merupakan jenis penelitian deskriptif analitik dengan rancangan cross sectional. Pengambilan sampel menggunakan teknik cluster untuk mendapatkan 8 sampel pasar. Data yang dikumpulkan yaitu data pengetahuan dan sikap dengan alat ukur kuesioner dan wawancara. Data penggunaan pewarna yang dilarang menggunakan metode Fenilhidrazin.

Hasil : Pedagang memiliki pengetahuan dalam kategori baik (87,5\%) sedangkan pedagang memiliki perbandingan sikap yang sama antara yang mendukung dan tidak mendukung (50\%) dan hasil uji laboratorium yang dilakukan di Universitas 17 Agustus menunjukan hasil negatif pada penggunaan pewarna yang dilarang tetapi terdapat 2 pasar menggunakan pewarna yang tidak dilarang yaitu Eritrosin.

Kesimpulan : Semua pedagang tidak menggunakan pewarna yang dilarang pada cenil dan putu mayang

Kata Kunci : Pegetahuan, Sikap, Penggunaan Pewarna yang dilarang 


\section{PENDAHULUAN}

Keamanan pangan menjadi penting dan perlu lebih diperhatikan oleh masyarakat. Makanan yang aman dan sehat akan memberikan dampak positif bagi orang yang mengkonsumsinya, sedangkan jika makanan tersebut tidak aman dan mengandung zat-zat berbahaya bagi tubuh, maka akan memberikan dampak negatif bagi orang yang mengkonsumsinya ${ }^{1}$.

Makanan yang selama ini diduga sebagi penyebab terjadinya kasus penyakit bawaan makanan dan keracunan makanan berasal baik dari masakan rumah tangga maupun makanan yang diperjualbelikan di tempat-tempat pengolahan makanan (TPM), diantaranya adalah makanan jajanan pasar ${ }^{2}$. Makanan jajanan pasar yang dijual di pasar-pasar banyak yang menggunakan bahan tambahan lain, seperti bahan pemanis, bahan penyedap, bahan pengawet, dan bahan pewarna. Bahan-bahan yang ditambahkan pada makanan jajanan psering ada yang membahayakan kesehatan manusia, seperti bahan-bahan pewarna yang dilarang ${ }^{3}$.

Penggunaan bahan pewarna yang dilarang pada pembuatan makanan jajanan pada umumnya untuk memberikan warna yang mencolok pada makanan sehingga dapat menarik konsumen untuk membeli. Bahan pewarna yang dilarang tidak boleh diberikan pada makanan karena dapat menyebabkan diare, kanker hati dan kerusakan ginjal. Kasus penyalahgunaan zat pewarna sebagai bahan tambahan pangan masih banyak dijumpai diberbagai daerah di Indonesia terutama di Pasarpasar ${ }^{4}$.

Menurut penelitian yang dilakukan oleh Sugiyatmi (2006) di Pasar Kota Semarang, diperoleh hasil dari 3 jenis sampel makanan (cenil, putu mayang dan sentiling) positif mengandung pewarna yang dilarang, yaitu cenil positif mengandung pewarna Orchil (merah), putu mayang positif mengandung Rose Bengal (merah muda) dan Guinea Green B (hijau), sedangkan sentiling positif mengandung Butter Yellow (kuning) dan Rose Bengal (merah muda) 5 .

Pada umumnya pedagang ataupun pembuat makanan jajanan pasar tidak menyadari bahaya penggunaan bahan tambahan yang dilarang. Hal ini disebabkan ketidaktahuan pedagang atau pembuat makanan jajanan pasar, baik mengenai sifat-sifat maupun bahaya penggunaan bahan tambahan pangan yang tidak sesuai dengan peraturan permenkes.

Berdasarkan hasil penelitian Pramastuty (2017) tentang faktor-faktor yang mempengaruhi keberadaan zat pewarna dan pengawet terlarang pada makanan jajanan di pasar-pasar tradisional
Kota Semarang, yaitu karena tingkat pendidikan, pengetahuan, sikap dan praktek dari penjual makanan jajanan yang rendah. Pengetahuan, sikap dan praktek pedagang makanan jajanan yang rendah memiliki pengaruh yang besar terhadap kualitas makanan yang dibuatnya ${ }^{6}$.

Tujuan penelitian ini untuk mengetahui hubungan tingkat pengetahuan dan sikap pedagang makanan jajanan pasar terhadap penggunaan pewarna yang dilarang di pasar-pasar Kota Semarang.

\section{METODE}

Penelitian ini merupakan penelitian bidang gizi institusi pada keamanan pangan. Termasuk dalam jenis penelitian deskriptif analitik. Rancangan yang digunakan adalah Rancangan Cross Sectional. Populasi dalam penelitian ini adalah semua pedagang makanan jajanan pasar yang ada di pasar-pasar Kota Semarang. Sampel penelitian dilipih dengan cara acak kelompok atau cluster ${ }^{7}$. Dari 53 pasar yang ada di Kota Semarang akan dipilih sejumlah pasar sebagai kelompok sampel, ditentukan dengan menggunakan rumus dari S.Lemeshow (1997) dalam Ariawan $(1998)^{8}$ dan diperoleh hasil 7,081 pasar sebagai kelompok sampel yang dibulatkan menjadi 8 pasar.

Banyaknya pasar yang digunakan sebagai kelompok sampel pada tiap wilayah ditentukan dengan rumus Sampling Fraction Per Cluster ${ }^{9}$. Dengan cara tersebut diperoleh nama-nama pasar kelompok sampel pada tiap wilayah yaitu Wilayah I Johar (pasar kanjengan), Wilayah II Karimata (pasar waru indah), Wilayah III Bulu (pasar sampangan), Wilayah IV Karangayu (pasar mangkang), Wilayah V Jatingaleh (pasar wonodri dan pasar jangli), Wilayah VI Pedurungan (pasar mrican dan pasar bangetayu). Pasar-pasar yang dipilih sebagai kelompok sampel pada tiap wilayah ditentukan secara acak, yaitu menggunakan tabel bilangan atau angka acak (random number) ${ }^{10}$.

Yang menjadi sampel pada penelitian ini adalah pedagang dan pembuat cenil, putu mayang dan cenil dan cenil, putu mayang yang bewarna mencolok. Pengambilan sampel diambil berdasarkan kriteria yang sudah ditentukan dan dilakukan 2 kali sebanyak 250 gr untuk tiap sampel. Pengujian untuk masing-masing sampel dilakukan secara duplo dan dilakukan pengulangan sampel sebanyak 2 kali dengan hari yang berbeda.

Instrumen yang digunakan terdiri dari formulir informed concern, formulir identitas dan karakteristik, kusioner pengetahuan tentang zat pewarna yang dilarang dan kuesioner sikap tentang zat pewarna yang dilarang. Uji laboratorium pewarna pada cenil dan putu mayang 
menggunakan uji kualitatif metode Fenilhidrazin yang dilakukan di Universitas 17 Agustus 1945 Semarang.

Analisis univariat bertujuan untuk menjelaskan atau mendiskripsikan data kategorik meliputi pengetahuan dan sikap mengenai pewarna yang dilarang serta penggunaan pewarna yang dilarang dibuat dalam bentuk tabel distribusi frekuensi. Analisis bivariat digunakan untuk menganalisis hubungan antar variabel yaitu variabel dependent (penggunaan pewarna yang dilarang) dan variabel independent (pengetahuan dan sikap pedagang makanan jajanan pasar). Analisis data menggunakan uji Chi-square ${ }^{11}$ dengan derajat kepercayaan $95 \%(\alpha=0,05)$.

\section{HASIL DAN PEMBAHASAN}

Penelitian ini dilakukan di pasar-pasar Kota Semarang sebanyak 8 pasar masing-masing pasar mendapatkan 1 sampel pedagang dan 1 sampel pedagang diambil 2 sampel makanan yaitu cenil dan putu mayang yang bewarna mencolok.

\section{A. Karakteristik Responden Menurut Umur}

Tabel 1. Distribusi Frekuensi Umur Pedagang

\begin{tabular}{ccc}
\hline Umur & $\mathrm{n}$ & Persentase (\%) \\
\hline$\geq 53$ tahun & 5 & 63 \\
$<53$ tahun & 3 & 37 \\
\hline Jumlah & 8 & 100 \\
\hline
\end{tabular}

Tabel 1 menunjukan bahwa umur pedagang makanan jajanan pasar sebanyak 5 orang $(63 \%)$ berumur $\geq 53$ tahun dan sebanyak 3 orang (37\%) berumur $<53$ tahun.

Umur dapat mempengaruhi daya tangkap dan pola pikir seseorang, semakin bertambahnya usia maka semakin berkembang daya tangkap dan pola pikir seseorang. Namun setelah melewati usia madya (40-60 tahun), daya tangkap dan pola pikir akan menurun ${ }^{12}$. Dengan adanya penyebaran informasi yang cepat dan mudah diakses di masa kini juga dapat mempengaruhi pengetahuan dan sikap responden ${ }^{13}$.

B. Karakteristik Responden Menurut Jenis Kelamin

Jenis kelamin menurut Hurlock adalah jenis kelamin laki-laki atau perempuan sudah ditentukan pada saat konsepsi dan sesudahnya tidak ada yang dapat mengubah jenis kelamin seseorang ${ }^{14}$. Di negara berkembang khususnya wanita memiliki pengetahuan yang rendah karena kurang mendapatkan informasi ${ }^{15}$.
Dari hasil penelitian menunjukan bahwa semua pedagang makanan jajanan pasar yang dijual dipasar-pasar Kota Semarang adalah Perempuan, walaupun semua responden pada penelitian ini adalah perempuan tidak menutup kemungkinan mereka mudah mendapatkan informasi yang dapat mempengaruhi pengetahuan dan sikap responden.

C. Karakteristik Responden Menurut Tingkat Pendidikan

Tabel 2. Distribusi Frekuensi Tingkat Pendidikan Pedagang

\begin{tabular}{ccc}
\hline Tingkat Pendidikan & $\mathrm{n}$ & Persentase (\%) \\
\hline Tidak Sekolah & 2 & 25 \\
Tamat Sekolah Dasar & 4 & 50 \\
Tamat Sekolah Menengah Atas & 2 & 25 \\
\hline Jumlah & 8 & 100 \\
\hline
\end{tabular}

Tabel 2 menunjukan bahwa sebagian besar tingkat pendidikan pedagang makanan jajanan pasar adalah tamat Sekolah Dasar sebanyak 4 orang $(50 \%)$ sedangkan sisanya sebanyak 2 orang (25\%) masing-masing yang berpendidikan Tidak Sekolah dan Tamat Sekolah Menengah Atas.

Tingkat pendidikan bukan satu-satunya faktor yang menentukan kemampuan seseorang untuk dapat mengembangkan pengetahuan dan sikap dalam melakukan suatu hal. Pengalaman yang pernah dialami di masa lalu juga dapat menentukan sikap seseorang terhadap suatu hal. Seseorang yang memiliki tingkat pendidikan yang rendah namun mendapatkan informasi yang baik dari televisi, radio, surat kabar, majalah dan juga dapat meningkatkan pengetahuan seseorang ${ }^{13}$. Hal ini menunjukan bahwa responden yang tingkat pendidikannya rendah mampu menerima informasi baru sehingga dapat mempengaruhi pengetahuan dan sikap responden.

\section{Pengetahuan Pedagang Makanan Jajanan Pasar Tentang Penggunaan Pewarna Yang Dilarang}

Dari hasil penelitian menunjukan bahwa skor pengetahuan tentang penggunaan pewarna yang dilarang diperoleh hasil minimal 70, maksimal 100 dan rata-rata 83,75 untuk lebih jelasnya dapat dilihat pada Tabel 3. 
Tabel 3. Distibusi Frekuensi Pengetahuan Pedagang Makanan Jajanan Pasar Tentang Pewarna Yang Dilarang

\begin{tabular}{ccc}
\hline Pengetahuan & Frekuensi & Persentase $(\%)$ \\
\hline Cukup & 1 & 12,5 \\
Baik & 7 & 87,5 \\
\hline Total & 8 & 100 \\
\hline
\end{tabular}

Tabel 3 menunjukan bahwa pedagang makanan jajanan pasar yang memiliki pengetahuan dalam kategori baik yaitu 7 orang $(87,5 \%)$ dan yang memiliki pengetahuan dalam kategori cukup yaitu 1 orang (12,5\%). Pedagang makanan jajanan pasar dikatakan memiliki tingkat pengetahuan tentang pewarna yang baik apabila memiliki skor $\geq 75 \%$.

Kebanyakan pedagang makanan jajanan pasar yang dijual di pasar-pasar Kota Semarang tidak mengetahui akibat penggunaan pewarna yang dilarang maupun yang tidak dilarang (sambang batas) pada kesehatan apabila dikonsumsi terus menerus karena selama responden berjualan mengetahui jika konsumen membeli dagangannya tidak pernah terjadi apa-apa.

Pengetahuan mengenai penggunaan pewarna makanan adalah kepandaian pedagang dalam penggunaan pewarna makanan yang diizinkan. Sebagian besar pedagang makanan jajanan pasar yang menjadi responden sudah mengetahui penggunaan pewarna alami dan dampak bagi kesehatan jika menggunakan pewarna alami kedalam makanannya.

Pengetahuan responden yang baik tentang penggunaan pewarna yang dilarang sesuai dengan karakteristik pendidikannya yaitu paling tinggi tamat Sekolah Menengah Atas. Pendidikan penting dalam pembentukan pengetahuan seseorang ${ }^{16}$. Karena pendidikan yang tinggi, pengetahuan yang dimiliki semakin luas. Namun tidak hanya pendidikan yang tamat Sekolah Menengah Atas saja yang mempunyai pengetahuan yang luas, tetapi pendidikan yang tamat Sekolah Dasar dan Tidak Sekolah pun juga mempunyai pengetahuan yang luas karena adanya perkembangan teknologi informasi. Responden mengaku mendapatkan informasi tentang penggunaan pewarna makanan melalui penyuluhan yang diadakan oleh puskesmas setempat, teman, media elektronik maupun media massa.

E. Sikap Pedagang Makanan Jajanan Pasar Tentang Penggunaan Pewarna Yang Dilarang
Dari hasil penelitian menunjukan bahwa sikap pedagang makanan jajanan pasar tentang penggunaan pewarna yang dilarang memiliki sikap mendukung sebesar $50 \%$ dan tidak mendukung sebesar $50 \%$ untuk lebih jelasnya dapat dilihat pada Tabel 4.

Tabel 4. Distribusi Frekuensi Sikap Pedagang Makanan Jajanan Pasar Tentang Pewarna Yang Dilarang

\begin{tabular}{ccc}
\hline Kategori & Frekuensi & Persentase $(\%)$ \\
\hline Mendukung & 4 & 50 \\
Tidak Mendukung & 4 & 50 \\
\hline Total & 8 & 100 \\
\hline
\end{tabular}

Tabel 4 menunjukan bahwa pedagang makanan jajanan pasar yang dijual di pasarpasar Kota Semarang memiliki perbandingan sikap yang sama antara yang mendukung dan tidak mendukung terhadap penggunaan pewarna yang dilarang.

Pedagang makanan jajanan pasar yang memiliki sikap mendukung karena memilih menggunakan pewarna alami dibandingkan menggunakan pewarna yang dilarang walaupun menggunakan pewarna alami harganya lebih mahal dan lebih sehat jika di konsumsi berkalikali. Sedangkan pedagang makanan jajanan pasar yang memiliki sikap tidak mendukung karena menggunakan pewarna sintetis/buatan harganya lebih murah dibandingkan dengan menggunakan pewarna alami dan penggunaan pewarna kedalam pembuatan makanan tidak perlu diatur agar warna pada makanan tersebut lebih menarik dan disukai konsumen.

Sikap yang mendukung akan menciptakan perilaku positif yang berifat langgeng apabila didukung dengan pengetahuan yang baik $^{16}$

\section{F. Penggunaan Pewarna yang Dilarang}

Hasil pemeriksaan pewarna yang dilarang pada makanan jajanan pasar dengan menggunakan metode Fenilhidrazin tercantum dalam Tabel 5

Tabel 5. Distribusi Frekuensi Penggunaan Pewarna Yang Dilarang Pada Makanan Jajanan Pasar

\begin{tabular}{cccc}
\hline \multirow{2}{*}{ Jenis Makanan Jajanan } & \multirow{2}{*}{} & \multicolumn{3}{c}{$\begin{array}{c}\text { Penggunaan Pewarna Yang } \\
\text { Dilarang }\end{array}$} \\
\cline { 3 - 4 } & & $(+)$ & $(-)$ \\
\hline Cenil & 8 & 0 & 8 \\
Putu Mayang & 8 & 0 & 8 \\
\hline Jumlah & 16 & 0 & 16 \\
\hline
\end{tabular}


Tabel 5 menunjukan bahwa semua sampel makanan jajanan pasar yang diteliti tidak mengandung pewarna yang dilarang. Hasil uji laboratorium menunjukan bahwa sampel makanan jajanan pasar menggunakan pewarna yang diperbolehkan menurut Peraturan Menteri Kesehatan Nomor 033 Tahun $2012^{17}$ yaitu pewarna Eritrosin dan sampel makanan pada penelitian ini adalah cenil dan putu mayang yang berwarna merah muda dan hijau.

Penggunaan Eritrosin di Indonesia masih diperbolehkan namun dengan syarat tidak melebihi ambang batas maksimal yang telah ditentukan dalam Peraturan Kepala Badan Pengawasan Obat dan Makanan Nomor 37 Tahun 2013 pada Pasal 3, ambang batas penggunaan eritrosin yaitu antara $20-300 \mathrm{mg} / \mathrm{kg}$ tergantung pada kategori pangan tertentu ${ }^{18}$. Berbeda dengan BPOM, menurut Arisman (2009) pewarna eritrosin sebagai pewarna yang tidak dianjurkan untuk pangan. Meskipun pewarna eritrosin diperbolehkan untuk pangan sebaiknya menghindari penggunaan pewarna sintetik apapun sebab pewarna sintetik tidak baik untuk kesehatan jika terus dikonsumsi ${ }^{19}$. Penggunaan eritrosin yang berlebihan dapat menyebabkan reaksi alergi pada pernapasan, hiperaktif pada anak, tumor tiroid pada tikus dan efek kurang baik pada otak dan perilaku ${ }^{20}$. Pada hasil laboratotium tidak menunjukan ambang batas pada pewarna Eritrosin, karena untuk menguji pewarna yang dilarang pada makanan jajanan pasar peneliti menggunakan uji kualitatif dengan metode Fenilhidrazin, maka peneliti tidak dapat mengetahui ambang batas yang menggunakan pewarna Eritrosin kedalam pembuatan cenil dan putu mayang.

\section{G. Hubungan Pengetahuan Dan Sikap Pedagang Makanan Jajanan Pasar Terhadap Penggunaan Pewarna Yang Dilarang}

Analisis bivariat antara variabel pengetahuan dan sikap pedagang makanan jajanan pasar terhadap penggunaan pewarna yang dilarang tidak dapat dilakukan uji statistik karena semua sampel makanan jajanan pasar negatif mengandung pewarna yang dilarang. Hal tersebut karena tidak ada ukuran perhimpunan yang bisa dihitung untuk kategori pengetahuan dan sikap terhadap penggunaan pewarna yang dilarang, setidaknya disetiap variabel mempunyai tabel 2 arah yang dapat diukur.

\section{KESIMPULAN}

Pengetahuan pedagang mengenai pewarna yang diolarang termasuk dalam kategorik baik yaitu sebesar $87,5 \%$. Sikap pedagang mengenai pewarna yang dilarang termasuk dalam kategori mendukung yaitu sebesar $50 \%$. Hasil identifikasi penggunaan pewarna yang dilarang pada cenil dan putu mayang adalah $100 \%$ negatif atau tidak mengandung pewarna yang dilarang. Hubungan antara variabel pengetahuan dan sikap pedagang makanan jajanan pasar terhadap penggunaan pewarna yang dilarang tidak dapat dianalisis menggunakan statistik karena hasil laboratorium menunjukan hasil negatif.

\section{SARAN}

Perlu adanya edukasi dan pembinaan dari Badan Pengawasan Obat Dan Makanan dan Dinas Kesehatan Kota Semarang tentang jenis-jenis pewarna pada makanan, ambang batas penggunaan pewarna yang diperbolehkan agar tidak terjadi penggunaan pewarna yang berlebihan dan dampak bagi kesehatan jika mengkonsumsi pewarna terus-menerus yang melebihi ambang batas dan perlu dilakukan uji kuantitatif untuk mengetahui ambang batas penggunaan pewarna yang terkandung dalam sampel.

\section{DAFTAR PUSTAKA}

1. BPOM. Keamanan Pangan. Direktorat Surveilan dan Penyuluhan Keamanan Pangan, Deputi Pengawasan Keamanan Pangan dan Bahan Berbahaya : Jakarta, 2003

2. Aritonang, I. Penyelenggaraan Makanan. Leutika dengan Cebios dan Jurusan Gizi Poltekkes Yogyakarta : Yogyakarta, 2012.

3. Lutfi Eliazer, S. Bahruddin, M. Aziz, A. Pembuatan Buku Makanan Tradisional Surabaya Sebagai Upaya Pelestarian Produk Lokal. Jurnal Desain Komunikasi Visual, 2013. Vol 1 (1).

4. Praja, Deni Indra. Zat Aditif Makanan Manfaat dan Bahayanya. Garudhawaca : Yogyakarta, 2015.

5. Sugiyatmi, S. Analisis Faktor-Faktor Risiko Pencemaran Bahan Toksik Boraks dan Pewarna pada Makanan Jajanan Tradisional yang Dijual di Pasar-Pasar Kota Semarang Tahun 2006. Skripsi. Semarang : Program Studi Magister Kesehatan Lingkungan, Program Pasca Sarjana, Universitas Diponegoro, 2006.

6. Pramastuty, Lailya. Raharjo, Mursid. Hanani, Yusniar. Faktor-Faktor Yang Mempengaruhi Keberadaan Zat Pewarna Dan Pengawet 
Terlarang Pada Makanan Jajanan Di PasarPasar Tradisional Kota Semarang. Jurnal Kesehatan Masyarakat, 2017. Vol 5 (1).

7. Notoatmodjo, Soekidjo. Metode Penelitian Kesehatan. PT Rineka Ciptaa : Jakarta, 2010. Hal 123

8. Ariawan, Iwan. Besar Dan Metode Sampel Pada Penelitian Kesehatan. Jurusan Biostatistik dan Kependudukan Fakultas Kesehatan Masyarakat Universitas Indonesia : Depok, 1998.

9. ANS (2009). Rumus-Rumus Pengambilan Sampel Penelitian. Available at: https://tesisdisertasi.blogspot.co.id/2009/12/ rumus-rumus-pengambilan-

sampel.html?m=1 (Accessed: 30 March 2018).

10. Notoatmodjo, Soekidjo. Metodologi Penelitian Kesehatan. PT Rineka Cipta: Jakarta, 2010. Hal 120-121.

11. Fajar, Ibnu. et al. Statistika uji Praktisi Kesehatan. Graha Ilmu : Yogyakarta, 2009.

12. Ugik. Semua Tentang Psikologi. Available at: http://allabout-

psikologi.blogspot.com/2009/11/dewasamadya.html (Accessed: 6 Aug 2018).

13. Hidayah R, Asterina, Afriadi. Hubungan Tingkat Pendidikan Dan Pengetahuan Penjual Es Campur Tentang Zat Pewarna Berbahaya Dengan Kandungan Rhodamin B Dalam Buah
Kolang Kaling Di Kota Padang. Jurnal Kesehatan Andalas, 2017. Vol 2 (6).

14. Ilmu Kedokteran. Karya Tulis IImiah. Available at: https://karyatulisilmiah.com/pengertianjenis-kelamin/ (Accessed: 6 Aug 2018).

15. Ifada I. Faktor-Faktor Yang Berhubungan Dengan Pengetahuan Masyarakat Mengenai Pelayanan Kesehatan Mata. Availabe at: http://eprints.undip.ac.id/23397/1/Ingga_I.p df (Accessed: 6 Aug 2018).

16. Notoatmodjo, Soekidjo. Pendidikan dan Perilaku Kesehatan. PT Rineka Cipta : Jakarta, 2003.

17. Permenkes RI. Permenkes No.033 Tahun 2012 Tentang Bahan Tambahan Pangan. Menteri Kesehaan Republik Indonesia : Jakarta, 2012.

18. Kepala BPOM RI. Peraturan Kepala Badan Pengawasan Obat Dan Makanan RI Nomor 37 Tahun 2013 Tentang Batas Maksimum Penggunaan Bahan Tambahan Pangan Pewarna. BPOM RI : Jakarta 2013.

19. Arisman. Keracunan Makanan. EGC : Jakarta, 2009.

20. Alifah, R. . (2012) Efek Samping Bahan Kimia Pewarna. Available at: http://alifahdreams.blogspot.com/2012/06/efeksamping-bahan-kimia-pewarna.html (Accessed: 29 June 2018 